\title{
Concurrent studies of the flow of digesta in the duodenum and of exocrine pancreatic secretion of calves
}

\author{
3.* Further studies on the addition of fat to skim milk and the use of \\ non-milk proteins in milk-substitute diets
}

\author{
BY J. H. TERNOUTH†, J. H. B. ROY, S. Y. THOMPSON, \\ JOYCE TOOTHILL, CATHERINE M. GILLIES \\ AND J. D. EDWARDS-WEBB \\ National Institute for Research in Dairying, \\ Shinfield, Reading $R G 2{ }_{9} A T$
}

(Received 20 March 1974 - Accepted 17 May 1974)

\begin{abstract}
I. The flow of digesta through the duodenum and the concurrent secretion of the pancreas were studied in four Friesian calves given four milk-substitute diets. The diets were: reconstituted, 'mildly' pre-heated, spray-dried skim-milk powder with (SKF) or without (SK) margarine fat or with $50 \%$ of the skim-milk powder in diet SKF replaced by soya-bean flour (ASKF) or fish-protein concentrate (BSKF), together with dried whey. The diets were given ad lib. twice daily from 13 to $37 \mathrm{~d}$ of age, each diet being given for 6 consecutive days. Collections of duodenal digesta and pancreatic secretions, from cannulas, were made for $12 \mathrm{~h}$ after feeding the 6th and $\mathrm{r} 2 \mathrm{th}$ meals ('experimental' meals) for each diet.

2. The diets fed as 'experimental' meals contained polyethylene glycol (PEG) as a fluid (whey) marker and goat's milk containing $\left[{ }^{3} \mathrm{H}\right]$ lysine as a marker for total protein; $\beta$-carotene
\end{abstract} was added as a lipid marker to the three diets containing margarine fat.

3. Over the $\mathrm{i} 2 \mathrm{~h}$ postprandial period, the patterns of duodenal digesta flow and secretion of pancreatic fluid did not differ markedly between the four diets. The abomasal outflow of both nitrogen and lipid in a $12 \mathrm{~h}$ postprandial period was related to their intakes from the 'penultimate' (5th and IIth) meals for diets SKF and SK but to their intakes at the 'experimental meals' for diets ASKF and BSKF. Secretion of pancreatic enzyme activity was highest during the Ist hour after feeding but the main outflow from the abomasum of total $\mathrm{N}$ and lipid occurred 5 -10 $\mathrm{h}$ after feeding.

4. The time required for all the whey marker (PEG) to pass through the duodenum was similar for diets SKF and SK, but only 53 and $42 \%$ respectively of the ingested protein marker passed through the duodenum in the $12 \mathrm{~h}$ after feeding. More acid appeared to be secreted by the abomasum when diet SK was given; also less undigested protein passed out of the abomasum after giving this diet. It is concluded that the physical absence of fat globules in the abomasal clot increases the degree of proteolysis.

5. The secretions of pancreatic fluid and pancreatic enzyme activity were all markedly lower for diet SK than for diet SKF.

6. With diets containing non-milk proteins (ASKF and BSKF), abomasal proteolysis was less efficient and the ingested protein passed out of the abomasum more rapidly than for diet SKF. There was no difference in the rate of abomasal outflow of the whey fluids between diets SKF, ASKF and BSKF.

7. In comparison with diet SKF, diets ASKF and BSKF tended to induce less pancreatic enzyme secretion over a $12 \mathrm{~h}$ postprandial period, with the exception of lipase.

8. There appeared to be no direct relationship between the quantities of any of the pancreatic enzymes secreted during a postprandial period and either the concurrent flow of duodenal digesta or the total quantities of dietary constituents passing through the duodenum.

* Paper no. 2: Br. $\mathcal{F}$. Nutr. (1974), 31, I3.

+ Present address: Department of Animal Husbandry, Faculty of Veterinary Science, University of Queensland, St Lucia, Queensland 4067, Australia. 
Ternouth, Roy \& Siddons (1974) showed that the composition of milk-substitute diets affected the secretion of pancreatic enzymes by calves. They found that the composition of the duodenal digesta after a feed was affected by the coagulation process in the abomasum, which resulted in a considerable delay in the outflow of partially-hydrolysed casein and fat and appeared to be of importance in ensuring adequate proteolysis of the milk protein.

To investigate further the degradation of the milk clot, the two diets used previously (Ternouth, Roy \& Siddons 1974), namely reconstituted, 'mildly' pre-heated, spraydried skim-milk powder with (SKF) or without (SK) the addition of fat, have been re-examined with the use of three markers: polyethylene glycol (PEG), for the fluid fraction of the ingesta, including non-coagulable protein, subsequently referred to as whey; $\beta$-carotene, for lipid; $\left[{ }^{3} \mathrm{H}\right]$ lysine-labelled goat's milk, for total protein. Two other diets in which $50 \%$ of the skim-milk powder was replaced either by a chemicallytreated soya-bean flour (ASKF) or by a fish (herring)-protein concentrate (BSKF), supplemented in both instances with spray-dried whey, have also been studied.

The digestive limitations which affect the feeding of non-milk proteins in milksubstitute diets to calves have not been fully elucidated. It is known that the feeding of soya-bean flour, either before or after removal of trypsin inhibitor, is associated with diarrhoea and poor growth in calves (Gorrill, Thomas, Stewart \& Morrill, I967; Colvin, Lowe \& Ramsey, I969; Colvin \& Ramsey, I969; Smith \& Wynn, 1971). Moreover, the low digestibility of soya-bean protein for calves at $21 \mathrm{~d}$ of age has been attributed to the lack of coagulation in the abomasum (Paruelle, Toullec, Frantzen $\&$ Mathieu, 1972).

\section{EXPERIMENTAL}

\section{Animals and management}

Four Friesian bull calves were given 71 colostrum during the first $4^{8} \mathrm{~h}$ of life and whole milk thereafter. They were cannulated at $3 \mathrm{~d}$ of age using a triple fistulation technique (technique I) (Ternouth \& Buttle, I973). The calves were vaccinated $5 \mathrm{~d}$ after surgery against Salmonellosis (Mellavax: Burroughs Wellcome \& Co., London), and after a further $5 \mathrm{~d}$ they received the first of the four milk-substitute diets.

The experimental design was a $4 \times 4$ randomized block, each of the four diets being given $a d l i b$. by teat at 09.00 and 21.00 hours for 6 successive days during which two collections were made. After the 6th and I 2 th meal, with each diet, complete collections of the duodenal digesta and pancreatic secretions were made for $12 \mathrm{~h}$ between 08.30 and $21.00 \mathrm{~h}$. The term 'penultimate' will be used to denote the 5 th and I Ith meals and 'experimental' to denote the 6th and I2th meals. The methods for collecting and returning the fluids were those of Ternouth \& Buttle (1973), except that the pancreatic-duodenal sac secretions were collected in a stainless-steel flask surrounded by an ice jacket. Every $\mathrm{I}$ or $2 \mathrm{~h}$ during a collection period, samples of pancreatic secretion were taken for enzyme assay. Trypsin inhibitor from soya bean (British Drug Houses, Poole, Dorset) was added $(0.5 \mathrm{mg} / \mathrm{ml})$ to the samples taken for lipase determinations before storage under nitrogen. Samples of duodenal digesta were taken for protein and fat analyses. All samples were stored at $-20^{\circ}$. 
Table I. Composition of four reconstituted-milk diets, with (SKF) or without (SK) fat, or containing soya-bean flour $(A S K F)$ or fish-protein concentrate $(B S K F)$ to replace $50 \%$ of the skim-milk powder in diet $S K F$, fed to four Friesian bull calves

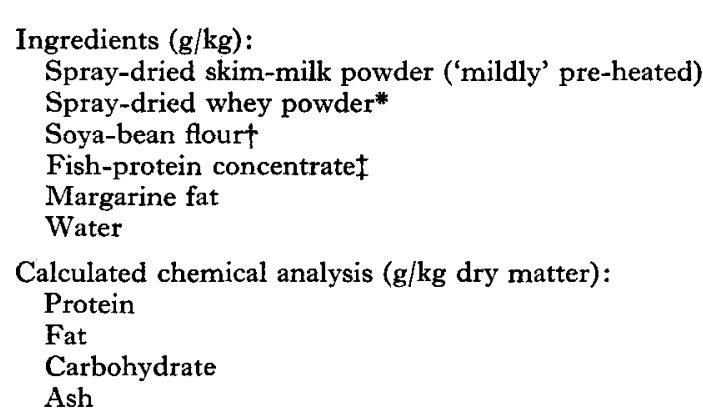

Measured mean concentration of electrolytes ( $\mathrm{mmol} / 1)$ :

Sodium

Potassium

Chloride

\begin{tabular}{rrrr} 
SKF & SK & ASKF & BSKF \\
100 & 100 & 50 & 50 \\
- & - & 23 & 35 \\
- & - & 27 & - \\
20 & - & \multicolumn{1}{c}{-} & 15 \\
880 & 900 & 880 & 880 \\
& & & \\
296 & 369 & 296 & 296 \\
210 & 13 & 210 & 209 \\
424 & 530 & 427 & 427 \\
69 & 87 & 65 & 76 \\
& & & \\
19.8 & 20.0 & $22 \cdot 0$ & $20 \cdot 3$ \\
22.1 & 22.8 & $25 \cdot 3$ & $21 \cdot 9$ \\
$31 \cdot 8$ & $31 \cdot 3$ & $38 \cdot 5$ & $31 \cdot 5$
\end{tabular}

Retinol II4I and cholecalciferol $24 \mu \mathrm{g} / \mathrm{kg}$ were added to each diet and $0.5 \mathrm{~g}$ DL-methionine (SAS, London) $/ \mathrm{kg}$ was added to diet ASKF.

* 'Krafco'; Kraft Foods Ltd, London.

† 'Nutramine' ('chemically-treated' soya-betan flour, 560 g protein/kg dry matter); Cargill Inc., Minneapolis, Minnesota, USA.

I 'Prot-Animal' (ground, 140 US Mesh, $870 \mathrm{~g}$ protein/kg dry matter); Astra Chemicals Ltd, Watford, Herts.

\section{Diets}

The three diets containing margarine fat, which was incorporated by homogenization, were formulated so that their proximal compositions were almost identical and they contained I00-I20 g dry matter/l (Table I). The composition of diets SK and SKF were similar to those used by Ternouth, Roy \& Siddons (1974). Diet ASKF, which included soya-bean flour, and diet BSKF, which included fish-protein concentrate, contained $4 \mathrm{I} 5$ and $373 \mathrm{~g}$ non-milk protein $/ \mathrm{kg}$ total protein respectively. As there was a tendency for some of the fish meal and soya-bean flour to settle out of solution, all four diets were stirred manually during feeding.

Goat's milk $(20-50 \mathrm{ml} / \mathrm{l})$ containing $\left[{ }^{3} \mathrm{H}\right]$ lysine, PEG $(\mathrm{Ig} / \mathrm{l})$ and $\beta$-carotene ( $5 \circ \mu \mathrm{g} / \mathrm{g}$ lipid) were incorporated as markers in the 'experimental' meals. The $\beta$-carotene was incorporated into the margarine fat of diets SKF, ASKF and BSKF when the fat for the 'experimental' meals was homogenized. The PEG and $\left[{ }^{3} \mathrm{H}\right] \mathrm{lysine}-$ labelled goat's milk were added to the 'experimental' meal immediately before it was warmed to $39^{\circ}$ for feeding.

The $\left[{ }^{3} \mathrm{H}\right] \mathrm{lysine}-\mathrm{labelled}$ goat's milk was prepared by giving goats intravenous injections of $20 \mathrm{mCi}\left[{ }^{3} \mathrm{H}\right]$ lysine. Collections of milk were made during the subsequent $7 \mathrm{~d}$ and $25 \%$ of the radioactivity was recovered. The goat's milk was incorporated into the diets to provide 10-40 $\times \mathrm{IO}^{3}$ disintegrations/min per ml diet. The higher levels of goat's milk were included in the diets when the calves were older and increasing background radioactivity was being recorded. It was considered that the increasing 
background radioactivity reflected recycling of $\left[{ }^{3} \mathrm{H}\right]$ lysine in the endogenous $\mathrm{N}$. The values for radioactivity in duodenal samples collected $0.5 \mathrm{~h}$ before, and $0.5, \mathrm{r} .5,3,5$, 7,9 and I $\mathrm{h}$ after the Ioth meal of each diet, together with those in the samples collected immediately before giving the 'experimental' meals were used to estimate the background radioactivity in the duodenal effluent at each 'experimental' meal. As there was little variation in the radioactivity for samples collected during the $\mathrm{I} 2 \mathrm{~h}$ postprandial period of the Ioth meal, a single background value for radioactivity was estimated for each calf for each diet.

The effect of the recirculation of ingested $\left[{ }^{3} \mathrm{H}\right]$ lysine in the endogenous fluid within a $\mathrm{I} 2 \mathrm{~h}$ collection period was also examined, because amino acids can appear in the pancreatic fluid within a few minutes of an intravenous injection (Neurath, 1962). After the completion of the main experiment a calf was given whole milk twice daily on 2 consecutive days, collections of digesta being made over $12 \mathrm{~h}$ periods. On the 2nd day, sufficient [ $\left.{ }^{3} \mathrm{H}\right]$ lysine-labelled goat's milk was added to the digesta returned to the duodenum to attain the maximum levels of radioactivity found in duodenal samples after an 'experimental' meal. From a comparison of the levels of radioactivity found in the two collections of digesta, it was concluded that the quantity of radioactivity recirculating in the duodenal effluent was not significantly increased during the course of the $12 \mathrm{~h}$ experimental period.

\section{Analytical methods}

In an earlier experiment (Ternouth, Roy \& Siddons, r974) the 'protein' $N$ in the duodenal effluent was determined by the Biuret reaction on the precipitate obtained by addition of trichloroacetic acid (TCA) to give a final concentration of $20 \mathrm{~g} / \mathrm{l}$. In the present experiment a similar procedure was used, but three 'protein'-N fractions were separated, namely those that were insoluble in 20,50 or $100 \mathrm{~g} \mathrm{TCA} / 1$, hereafter referred to as $20 \mathrm{PN}, 5 \circ \mathrm{PN}$ and $100 \mathrm{PN}$ respectively.

Sodium, potassium, chloride, PEG and total N (TN) contents were measured by the methods described by Ternouth, Roy \& Siddons (1974).

Lipids were extracted by the technique of Folch, Lees \& Sloane Stanley (1957) as used for blood serum (Nelson \& Freeman, 1959). Lipid in the duodenal samples included not only the true lipids and phospholipids, mainly from the bile, but also non-lipids (including PEG) extracted by chloroform-methanol and not removed by the aqueous wash; concentrations were adjusted to allow for PEG.

The $\beta$-carotene content of the lipid was determined by the method of Kon \& Thompson (1957). Recovery of $\beta$-carotene from duodenal digesta was found to be ro $\%$ less than from the diet and also to decrease with decreasing $\mathrm{pH}$ of the digesta. All $\beta$-carotene values were adjusted for both these sources of underestimation.

\section{Measurement of radioactivity}

The scintillation solutions used were: 'Poly 46r' ( $7 \mathrm{~g} \mathrm{2,5-diphenyloxazole,} 0.3 \mathrm{~g}$ $\mathrm{I}, 4$-di(2-(5-phenyloxazolyl))benzene and $100 \mathrm{~g}$ naphthalene in $400 \mathrm{ml}$ anisole and $600 \mathrm{ml}$ 2-methoxyethanol) and 'Normal Poly' (6 g 2(4'-t-butylphenyl)-5-(4"-bi- 
phenylyl)-1,3,4-oxadiazole and $0.3 \mathrm{~g} \mathrm{x}, 4$-di(2-(5-phenyloxazolyl))benzene in $\mathrm{I} 1$ toluene).

Milk samples were prepared for specific radioactivity measurement by the addition of $0.5 \mathrm{ml}$ milk to $0.5 \mathrm{ml}$ hyamine hydroxide (Nuclear Enterprises, Edinburgh) in disposable glass vials, and agitation of the mixture at $40^{\circ}$ for $10 \mathrm{~min}$. 'Poly $46 \mathrm{I}$ ' ( $10 \mathrm{ml}), 2 \mathrm{M}-\mathrm{HCl}(0.2 \mathrm{ml})$ and 'Normal $\mathrm{Poly}_{\mathrm{y}}(3 \mathrm{ml})$ were added separately and swirled into the mixture. The duodenal samples were prepared in a similar manner except that $\mathrm{I} \mathrm{ml}$ samples were used and the $2 \mathrm{M}-\mathrm{HCl}$ was omitted. The radioactivity in all samples was estimated using a Tri-carb liquid scintillation spectrophotometer (Model 3003; Packard Instrument Co. Inc., Downers Grove, Illinois, USA). The counting efficiency of each sample was determined from the addition of $0.2 \mathrm{ml}$ standard containing a known quantity of ${ }^{3} \mathrm{H}$.

\section{Pancreatic enzyme activity}

The $\alpha$-amylase ( $E C$ 3.2.1.1), protease and trypsin $\left(E C C_{3.4 .4 .4)}\right.$ activity in pancreatic fluid were measured as described by Ternouth, Roy \& Siddons (I974).

The activity of $\alpha$-chymotrypsin ( $E C$ 3.4.4.5) was measured using the synthetic substrate $N$-benzoyl-L-tyrosine ethyl ester as described by Hummel (1959) except that the buffer and methanol solutions were prepared separately and only mixed in the cuvette of the spectrophotometer (Worthington Biochemicals Corporation, I972a). Before being assayed, pancreatic secretions were incubated for $2 \mathrm{~h}$ at $4^{\circ}$ for full activation to occur. Bovine chymotrypsin (British Drug Houses Ltd, Poole, Dorset) was used as a reference standard and $0.1 \mathrm{mg}$ gave a change in extinction at $256 \mathrm{~nm}$ of $0.516 \mathrm{units} / \mathrm{min}$.

Lipase activity was measured using an olive-oil substrate as described by MarchisMouren, Sarda \& Desnuelle (I959); the method was modified by (I) the use of a lower assay temperature $\left(25^{\circ}\right)$ and $\mathrm{pH}(8 \cdot 5),(2)$ the addition of oleic acid to the olive oil (Mattson \& Volpenhein, 1969) and (3) the addition of $\mathrm{NaCl}$ and $\mathrm{CaCl}_{2}$ to the substrate (Worthington Biochemicals Corporation, $1972 b$ ). An emulsion was prepared which could be stored for at least I week; the majority of the fat particles were about $0.5 \mu \mathrm{m}$ in diameter. Porcine pancreatic lipase (EC 3.r.r.3, salt-free lyophilized preparation PLi II, Worthington Biochemical Corporation, New Jersey, USA) was used to check the substrate which was prepared daily. The samples were assayed within $3 \mathrm{~d}$ of collection, each being thawed below $4^{\circ}$ immediately before use and diluted with cold $0.005 \mathrm{M}-\mathrm{CaCl}_{2}$. The acid released by the enzyme from the substrate over the first $5 \mathrm{~min}$ was titrated automatically using $0.005 \mathrm{M}-\mathrm{NaOH}$; I unit of activity is the amount of enzyme which liberates I $\mu \mathrm{mol} \mathrm{acid} / \mathrm{min}$.

Ribonuclease activity was measured after dilution of the pancreatic fluid I: 100 $(\mathrm{v} / \mathrm{v})$ with de-ionised water. The diluted fluid $(0 \cdot \mathrm{r} \mathrm{ml})$ was incubated for $15 \mathrm{~min}$ at $30^{\circ}$ with $0.9 \mathrm{ml}$ reprecipitated sodium salt of ribonucleic acid (British Drug Houses Ltd, Poole, Dorset) $(7.5 \mathrm{mg} / \mathrm{ml}$ 0.125 M-Tris(hydroxymethyl)methylamine, $\mathrm{pH} 7 \cdot 3$ ), I $\mathrm{ml}$ TCA solution (prepared by adding a solution of $5 \mathrm{~g} \mathrm{La}\left(\mathrm{NO}_{3}\right)_{3} \cdot 6 \mathrm{H}_{2} \mathrm{O} / 1$ to $100 \mathrm{~g}$ TCA to give a final volume of $\mathrm{I}$ l) was then added and the mixture was placed in an ice bath for ${ }_{15} \mathrm{~min}$. The incubation medium was then centrifuged, $0.5 \mathrm{ml}$ of the super- 
Table 2. Mean intake ( $l$ ) at the 'penultimate' and 'experimental' meals* when four Friesian bull calves were given four reconstituted-milk diets, with $(S K F)$ or without $(S K)$ fat, or containing soya-bean flour $(A S K F)$ or fish-protein concentrate $(B S K F)$ to replace $50 \%$ of the skim-milk pozvder in diet $S K F$

\begin{tabular}{|c|c|c|c|c|c|}
\hline & \multicolumn{4}{|c|}{ Diet $\dagger$} & \multirow[b]{2}{*}{$\mathrm{SE}$ of mean (2I df) } \\
\hline & SKF & SK & ASKF & BSKF & \\
\hline enultimate' meal & $3 \cdot 19$ & $3 \cdot 17$ & 3.72 & $3 \cdot 17$ & 0.29 \\
\hline 'Experimental' meal & $3 \cdot 30$ & 4.03 & $4: 32$ & $3 \cdot 70$ & 0.32 \\
\hline
\end{tabular}

* 'Experimental' meals, meals 6 and 12 from the beginning of the experimental period; 'penultimate' meals, meals 5 and II.

† Contained: SKF, skim-milk powder and fat; SK, skim-milk powder; ASKF, soya-bean flour, spray-dried whey powder, skim-milk powder and fat; BSKF, fish-protein concentrate, spray-dried whey powder, skim-milk powder and fat; for details, see Table I.

natant fraction was mixed with $10 \mathrm{ml}$ de-ionized water, and the extinction at $260 \mathrm{~nm}$ was measured. Bovine ribonuclease (British Drug Houses Ltd, Poole, Dorset) was used as a reference standard. Under these conditions, I $\mu$ g bovine ribonuclease gave a change in extinction of 0.88 units/min.

The sodium salt of ribonucleic acid was prepared by dissolving $10 \mathrm{~g}$ of the crude salt obtained from yeast (British Drug Houses Ltd, Poole, Dorset) in $15^{\circ} \mathrm{ml} \mathrm{NaCl}$ solution ( $100 \mathrm{~g} / \mathrm{l})$ and incubating the mixture at $90^{\circ}$ for $\mathrm{I} h$. When cool, any precipitate was removed, $45^{\circ} \mathrm{ml}$ ethanol was added and the mixture was allowed to stand overnight. The precipitate was collected by filtration and dried using ethanol-diethyl ether and then diethyl ether.

\section{Statistical analysis}

Analysis of variance and covariance adjustment techniques were used.

\section{RESULTS}

The mean birth weight of the calves was $42.5 \mathrm{~kg}$, and the mean gain in weight from birth to the end of the experiment at $39 \mathrm{~d}$ was $\mathrm{r} 3.5 \mathrm{~kg}$.

All four diets were readily consumed. The mean intakes at the 'penultimate' and 'experimental' meals are given in Table 2. There was no significant difference between diets.

The patterns of outflow of whey and electrolytes were similar to those recorded in an earlier experiment (Ternouth, Roy \& Siddons, 1974). Even after some values had been adjusted for differences between treatments in the intake of diet, there was no significant difference in either the pattern or the total outflow of any of the whey components of the duodenal digesta (Table 3 ), except for a higher outflow of $\mathrm{K}^{+}$for diet ASKF. There was no significant difference between diets in the pattern of PEG outflow or in the theoretical time in which all the PEG would have been recovered from the abomasum, calculated from extrapolation of values by means of the square root function (Ternouth, Roy \& Siddons, 1974).

The volume of fluid and the calculated concentrations of $\mathrm{Na}^{+}$and $\mathrm{Cl}^{-}$which passed 
Table 3. Total outflow of fluid $(l)$ and hydrogen, sodium, potassium and chloride ions (mmol), and time for complete recovery of polyethylene glycol (PEG) from the duodenal digesta, of four Friesian bull calves during $12 h$ after receiving four reconstituted-milk diets, with $(S K F)$ or without $(S K)$ fat, or containing soya-bean flour $(A S K F)$ or fishprotein concentrate $(B S K F)$ to replace $50 \%$ of the skim-milk powder in diet $S K F$

\begin{tabular}{|c|c|c|c|c|c|c|}
\hline & & & & & & \\
\hline & adjustment & SKF & SK & ASKF & BSKF & SE of mean \\
\hline Volume & $* * *$ & 6.45 & 6.05 & $6 \cdot 17$ & $6 \cdot 18$ & 0.16 \\
\hline $\mathrm{H}^{+}$ & NS & 478 & 4.03 & $4 \cdot 55$ & 5.04 & I.OI \\
\hline $\mathrm{Na}^{+}$ & NS & 248.8 & $239^{\circ} 0$ & $262 \cdot 1$ & $235 \cdot 1$ & $11 \cdot 7$ \\
\hline $\mathbf{K}^{+}$ & $* * *$ & $72 \cdot 5$ & $67 \cdot 8$ & $8 \mathfrak{3} \cdot 8$ & $69 \cdot 5$ & 3.4 \\
\hline $\mathrm{Cl}^{-}$ & $* * *$ & $6 I_{4} \cdot 1$ & $577 \cdot 7$ & $56 r \cdot 8$ & $602 \cdot 8$ & $22 \cdot 0$ \\
\hline PEG recovery time $(h)$ & NS & II.O & II:6 & $10 \cdot 4$ & II 0 & 0.9 \\
\hline
\end{tabular}

NS, mean values not significantly related $(P>0.05)$ to liquid intake at the 'experimental' meal; no adjustment made for dietary intake.

Mean values significantly related to liquid intake at the 'experimental' meal: $* * * P<0.001$; mean values and SE adjusted to dietary intake of 3.841 .

+ Contained: SKF, skim-milk powder and fat; SK, skim-milk powder; ASKF, soya-bean flour, spray-dried whey powder, skim-milk powder and fat; BSKF, fish-protein concentrate, spray-dried whey powder, skim-milk powder and fat; for details, see Table $\mathrm{r}$.

Table 4. Volume $(l)$ and sodium and chloride ion concentration (mmol/l) of fluids, in excess of those ingested, passing through the duodenum of four Friesian bull calves during I $2 h$ after receiving four reconstituted-milk diets, with $(S K F)$ or without $(S K)$ fat, or containing soya-bean flour $(A S K F)$ or fish-protein concentrate $(B S K F)$ to replace $50 \%$ of the skim-milk powder in diet $S K F$

\begin{tabular}{|c|c|c|c|c|c|}
\hline & \multicolumn{4}{|c|}{ Diet† } & \multirow[b]{2}{*}{ SE of mean } \\
\hline & SKF & SK & ASKF & BSKF & \\
\hline Volume & $2 \cdot 64$ & $2 \cdot 20$ & $2 \cdot 30$ & $2 \cdot 35$ & 0.15 \\
\hline $\mathrm{Na}^{+}$ & $7 \times \cdot 7$ & $74 \cdot 8$ & $75 \cdot 4$ & $69 \cdot 5$ & $6 \cdot 2$ \\
\hline $\mathrm{Cl}^{-}$ & $180 \cdot 2$ & $219^{\circ} 9^{*}$ & 185.6 & $201 \cdot 3$ & 10.0 \\
\hline $\mathrm{Cl}^{-}$minus $\mathrm{Na}^{+}$ & $108 \cdot 5$ & $145 \cdot I^{*}$ & $115 \cdot 2$ & $131 \cdot 8$ & $9 \cdot 9$ \\
\hline
\end{tabular}

Mean values significantly different from those for $\operatorname{diet}$ SKF: $* P<0.05$.

$\uparrow$ Contained: SKF, skim-milk powder and fat; SK, skim-milk powder; ASKF, soya-bean fiour, spray-dried whey powder, skim-milk powder and fat; BSKF, fish-protein concentrate, spray-dried whey powder, skim-milk powder and fat; for details, see Table $\mathrm{I}$.

through the duodenum in excess of those ingested are shown in Table 4. There was a tendency for more apparent secretion to pass through the duodenum when diet SKF was given. Although the volume of apparent secretion was least with diet SK, the concentrations of $\mathrm{Cl}^{-}$and $\left(\mathrm{Cl}^{-}\right.$minus $\left.\mathrm{Na}^{+}\right)$for this diet were considerably higher than those for the other diets.

The quantity of 'TN recovered in the duodenal digesta was related to the quantity of diet ingested at both the 'penultimate' and 'experimental' meals. After adjustment of the mean values for differences in intake between diets, the quantity of TN recovered in the $\mathrm{I} 2 \mathrm{~h}$ period did not differ significantly between diets (Table 5 ). 
Table 5. Flow of nitrogen $(T N)$, protein- $N(P N)$ and lipid through the duodenum of four Fresian bull calves during $12 h$ after receiving four reconstituted-milk diets, with $(S K F)$ or without $(S K)$ fat, or containing soya-bean flour $(A S K F)$ or fish-protein concentrate $(B S K F)$ to replace $50 \%$ of the skim-milk powder in diet $S K F$

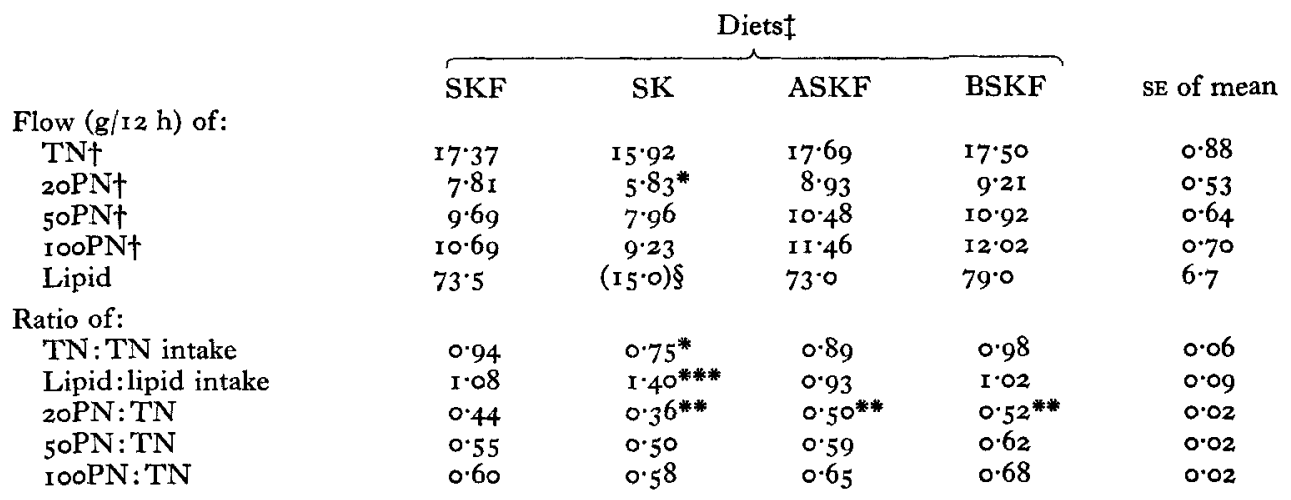

$20 \mathrm{PN}, 5 \circ \mathrm{PN}$, 100PN; protein- $\mathrm{N}$ insoluble in 20,50 and $100 \mathrm{~g}$ trichloroacetic acid $/ 1$ respectively.

Mean values significantly different from those for $\operatorname{diet~SKF:~}{ }^{*} P<0.05$, ** $P<0.01$, *** $P<0.00 \mathrm{r}$. $\dagger$ Mean values significantly related $(P<0.00 \mathrm{I})$ to intake at both 'penultimate' and 'experimental' meals (meals 5 and $I I$, and 6 and 12 from the beginning of the experimental period, respectively); mean values and SE adjusted by covariance.

$\ddagger$ Contained: SKF, skim-milk powder and fat; SK, skim-milk powder; ASKF, soya-bean flour, spray-dried whey powder, skim-milk powder and fat; BSKF, fish-protein concentrate, spray-dried whey powder, skim-milk powder and fat; for details, see Table I.

$\S$ Diet excluded from statistical analysis.

However, the TN collected in the duodenal digesta was considerably less than the TN intake when the 'experimental' meal was diet SK. The outflow of each fraction of $\mathrm{PN}$ and the $\mathrm{PN}: \mathrm{TN}$ ratio differed markedly between treatments and was in the order: $\mathrm{SK}<\mathrm{SKF}<\mathrm{ASKF}<\mathrm{BSKF}$ (Table 5). The recovery of lipid after giving diets SKF, ASKF and BSKF did not differ significantly from the intake, but with diet SK the recovery was considerably greater than the intake.

The patterns of outflow of TN, PN and lipid did not differ significantly between diets (Ternouth, 197I) and were similar to those reported for an earlier experiment (Ternouth, Roy \& Siddons, I974). An over-all multiple regression equation was fitted for the relationship between $\mathrm{TN}(\mathrm{g})$ in the duodenal digesta and the intake (l) of diet at the 'penultimate' (PM) and 'experimental' (M) meals. A similar regression was calculated for lipid (TL; g) in the duodenal digesta $v$. lipid intake $(\mathrm{g})$ at the 'penultimate' (PL) and 'experimental' (ML) meals. The equations were:

(a) for all diets,

$$
\begin{aligned}
& \mathrm{TN}=3 \cdot 8 \mathrm{r}+1 \cdot 28 \mathrm{PM}+2 \cdot 327 \mathrm{M} * * \text { (sD } 2 \cdot 86,29 \mathrm{df}), \\
& ( \pm 0.73) \quad( \pm 0.67) \\
& \mathrm{TL}=13.32+0.270 \mathrm{PL}^{*}+0.573 \mathrm{ML} * * * \text { (SD 12.21, } 29 \mathrm{df} \text { ); } \\
& ( \pm 0.101)( \pm 0.103)
\end{aligned}
$$



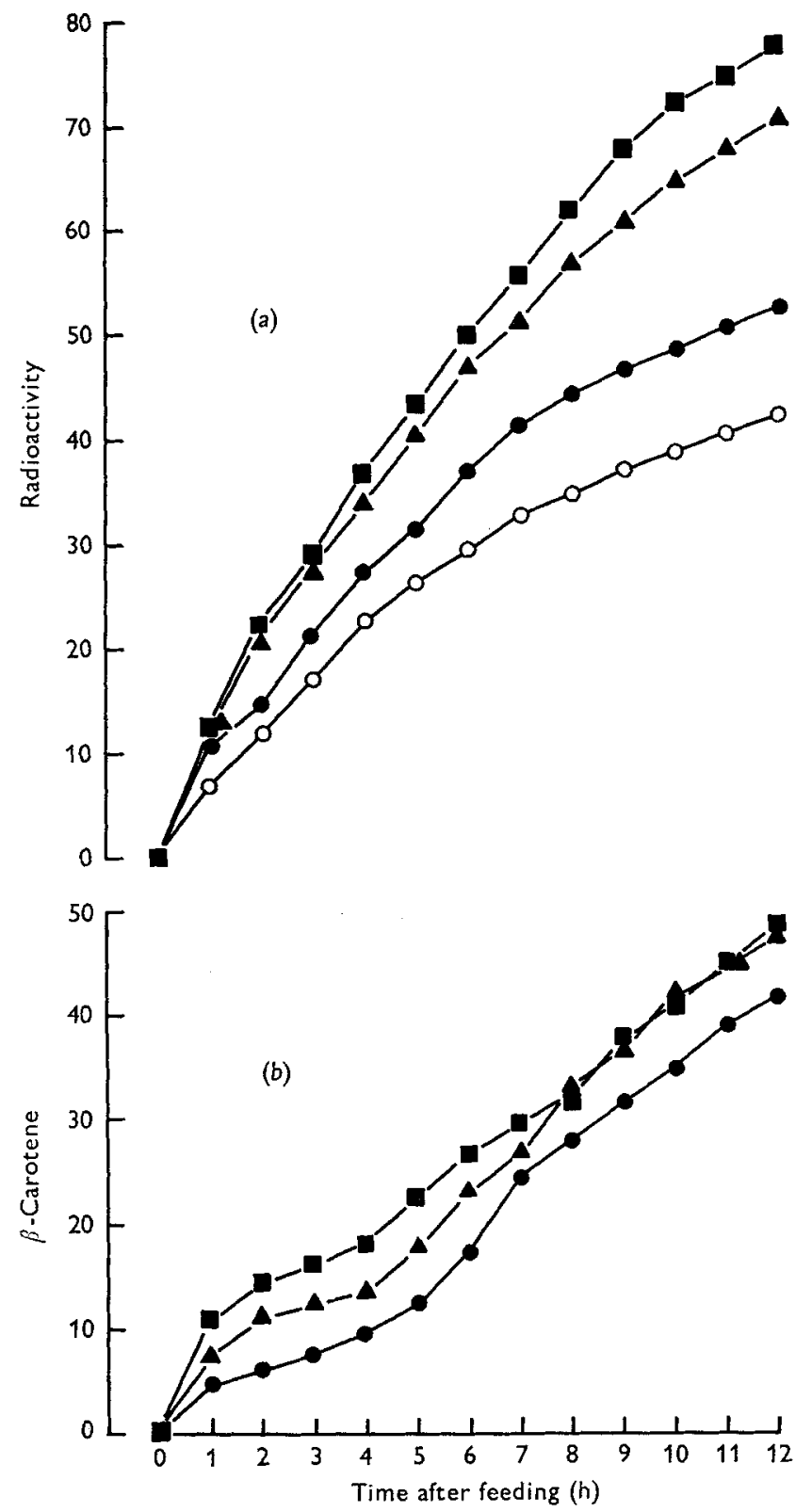

Fig. r. Cumulative recovery $(\%)$ of $(a)\left[{ }^{3} \mathrm{H}\right]$ lysine and $(b) \beta$-carotene in the duodenal effluent of four Friesian bull calves given four reconstituted-milk diets. (O) Diet SKF, (O) diet SK, (a) diet ASKF, (A) diet BSKF; for details of diets, see Table r. 


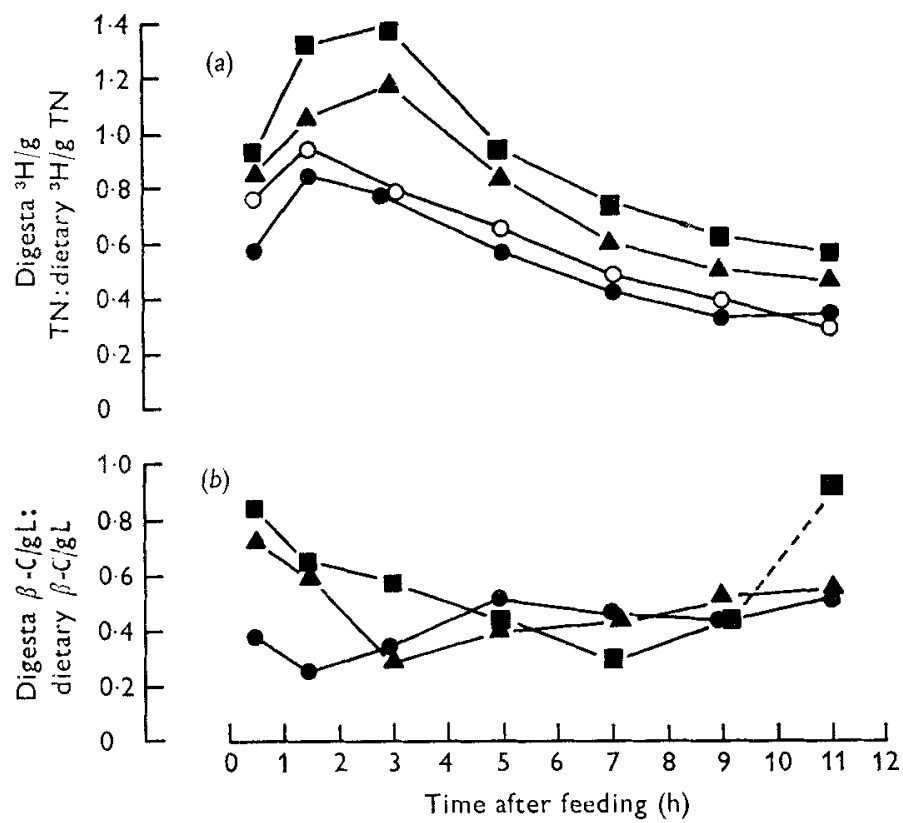

Fig. 2. Variations in $(a)$ the amount of $\left[{ }^{3} \mathrm{H}\right]$ lysine $\left({ }^{3} \mathrm{H}\right) / \mathrm{g}$ total nitrogen $(\mathrm{TN})$ in the duodenal digesta: the amount of ${ }^{3} \mathrm{H} / \mathrm{g}$ TN in the diet and $(b)$ the amount of $\beta$-carotene $(\beta-\mathrm{C}) / \mathrm{g}$ lipid (L) in the duodenal digesta: the amount of $\beta-\mathrm{C} / \mathrm{g} \mathrm{L}$ in the diet, for four Friesian bull calves given four reconstituted-milk diets. (O) Diet SKF, (O) diet SK, ( $\boldsymbol{\square}$ ) diet ASKF, (A) diet BSKF; for details of diets, see Table $\mathrm{I}$.

(b) for diets SKF and SK,

$$
\begin{aligned}
& \mathrm{TN}=3 \cdot 52+2 \cdot \mathrm{I}_{4} \mathrm{PM}^{*}+\mathrm{I} \cdot 54 \mathrm{M}\left(\mathrm{SD} 2 \cdot 62, \mathrm{I}_{3} \mathrm{df}\right), \\
& ( \pm 0.88) \quad( \pm 0.8 \mathrm{I}) \\
& \mathrm{TL}=14 \cdot 25+0.514 \mathrm{PL}^{* *}+0.328 \mathrm{ML}\left(\mathrm{SD} \text { I } 1 \cdot 36, \mathrm{I}_{3} \mathrm{df}\right) ; \\
& ( \pm 0.145) \quad( \pm 0.160)
\end{aligned}
$$

(c) for diets ASKF and BSKF,

$$
\begin{gathered}
\mathrm{TN}=5.90+0.87 \mathrm{PM}+2.33 \mathrm{M}^{*}\left(\mathrm{SD} 2.99, \mathrm{I}_{3} \mathrm{df}\right), \\
( \pm \mathrm{I} \cdot \mathrm{I} 8) \quad( \pm \mathrm{I} \cdot \mathrm{I} 2) \\
\mathrm{TL}=27.06-0.012 \mathrm{PL}+0.682 \mathrm{ML}^{* * *}\left(\mathrm{SD} \mathrm{II}_{1} \cdot 89, \mathrm{I}_{3} \mathrm{df}\right) ; \\
( \pm 0.177)( \pm 0.133)
\end{gathered}
$$

significance levels: $* P<0.05, * * P<0.01, * * * P<0.001$.

The quantity of $\left[{ }^{3} \mathrm{H}\right]$ lysine recovered in the digesta within $3 \mathrm{~h}$ of a feed differed significantly between diets (Fig. $\mathrm{r}$ ). By the end of the $\mathrm{I} 2 \mathrm{~h}$ period, the mean quantities of $\left[{ }^{3} \mathrm{H}\right]$ lysine recovered for diets SKF, SK, ASKF and BSKF were $0.53,0.42$, 0.78 and $0.7 \mathrm{r}$ (SE of mean 0.04 ) respectively of that ingested at the 'experimental' meals. The ratio of amount of $\left[{ }^{3} \mathrm{H}\right] \mathrm{lysine} / \mathrm{g} \mathrm{TN}$ in the duodenal digesta: the amount of $\left[{ }^{3} \mathrm{H}\right]$ lysine/g TN in the diet, for diets ASKF and BSKF, was significantly higher than that for diets SKF and SK throughout the collection periods (Fig. 2). During 
Table 6. Secretion of pancreatic fluid and enyzmes by four Friesian bull calves during $12 h$ after receiving four reconstituted-milk diets, with (SKF) or without (SK) fat, or containing soya-bean flour $(A S K F)$ or fish-protein concentrate $(B S K F)$ to replace $50 \%$ of the skim-milk powder in diet $S K F$

\begin{tabular}{|c|c|c|c|c|c|c|}
\hline & \multicolumn{4}{|c|}{ Diet $\ddagger$} & \multirow[b]{2}{*}{$\mathrm{SE}$ of mean } \\
\hline & & SKF & SK & ASKF & BSKF & \\
\hline Volume & $\begin{array}{l}(\mathrm{ml}) \\
(/ 1 \mathrm{diet})\end{array}$ & $\begin{array}{r}293 \cdot 3 \\
92 \cdot 6\end{array}$ & $\begin{array}{c}260 \cdot 4 \\
68 \cdot 4^{*}\end{array}$ & $\begin{array}{r}35 I \cdot 1 \\
72 \cdot 9\end{array}$ & $\begin{array}{r}293 \cdot 8 \\
91 \cdot 3\end{array}$ & $\begin{array}{r}14.9 \dagger \\
7.3 \dagger\end{array}$ \\
\hline Trypsin & $\begin{array}{l}\text { (mg) } \\
\text { (/1 diet) } \\
\text { (/g digesta } \mathrm{TN}) \\
(/ \mathrm{g} \text { digesta } 20 \mathrm{PN})\end{array}$ & $\begin{array}{r}272 \cdot 9 \\
85 \cdot 4 \\
17 \cdot 5 \\
39 \cdot 9\end{array}$ & $\begin{array}{c}24 \mathrm{I} \cdot 0 \\
59^{\cdot} \cdot 8^{*} \\
15 \cdot 5 \\
43 \cdot 3\end{array}$ & $\begin{array}{r}297 \cdot 6 \\
68 \cdot 7 \\
15 \cdot 3 \\
3 I \cdot 2\end{array}$ & $\begin{array}{r}260 \cdot 8 \\
70 \cdot 6 \\
15.5 \\
29 \cdot I^{*}\end{array}$ & $\begin{array}{l}23 \cdot 1 \dagger \\
7 \cdot 6 \\
1 \cdot 4 \\
3 \cdot 33\end{array}$ \\
\hline Chymotr & $\begin{aligned} \operatorname{ypsin} & (\mathrm{g}) \\
& (/ \mathrm{l} \text { diet }) \\
& (/ \mathrm{g} \text { digesta } \mathrm{TN} \\
& (/ \mathrm{g} \text { digesta } 20 \mathrm{PN})\end{aligned}$ & $\begin{array}{l}I .29 \\
0.411 \\
0.08 I \\
0.180\end{array}$ & $\begin{array}{l}1.02 \\
0.254^{* * *} \\
0.063 \\
0.174\end{array}$ & $\begin{array}{l}I \cdot 28 \\
0.296 * \\
0.066 \\
0.134\end{array}$ & $\begin{array}{l}\mathrm{r} \cdot \mathrm{x} 6 \\
0.310^{*} \\
0.067 \\
0.125^{*}\end{array}$ & $\begin{array}{l}0.12 \dagger \\
0.033 \dagger \\
0.009 \dagger \\
0.016\end{array}$ \\
\hline Protease & $\begin{array}{l}\text { (g) } \\
\text { (/I diet) } \\
(/ \mathrm{g} \text { digesta } \mathrm{TN}) \\
(/ \mathrm{g} \text { digesta } 20 \mathrm{PN})\end{array}$ & $\begin{array}{l}6.00 \\
I \cdot 87 \\
0.39 \\
0.89\end{array}$ & $\begin{array}{l}5 * 45 \\
x \cdot 31 * \\
0.34 \\
0.93\end{array}$ & $\begin{array}{l}6 \cdot 62 \\
1 \cdot 55 \\
0 \cdot 34 \\
0 \cdot 71\end{array}$ & $\begin{array}{l}5 \cdot 14 \\
1 \cdot 42 \\
0.31 \\
0.60^{*}\end{array}$ & $\begin{array}{l}0.52 \\
0.14 \\
0.03 t \\
0.08 t\end{array}$ \\
\hline Lipase & $\begin{array}{l}(\mathrm{kU}) \S \\
(/ 1 \text { diet }) \\
\text { (/g digesta lipid) }\end{array}$ & $\begin{array}{r}19 \cdot 70 \\
6 \cdot 25 \\
267\end{array}$ & $\begin{array}{c}16 \cdot 86^{*} \\
4 \cdot 07 \\
\operatorname{II} 34^{* * *}\end{array}$ & $\begin{array}{l}25 \cdot 00^{*} \\
5 * 75 \\
375\end{array}$ & $\begin{array}{l}25.55^{*} \\
7.03 \\
317\end{array}$ & $\begin{array}{l}\text { r.23† } \\
0.80 \dagger \\
95.9 \dagger\end{array}$ \\
\hline Amylase & $\begin{array}{l}(\mathrm{mg}) \\
(/ \mathrm{I} \text { diet })\end{array}$ & $\begin{array}{l}2 I \cdot I \\
6 \cdot 84\end{array}$ & $\begin{array}{l}\text { I } 5.7 \\
3.75^{* * *}\end{array}$ & $\begin{array}{l}19.9 \\
4.65^{*}\end{array}$ & $\begin{array}{l}\text { I } 9 \cdot 8 \\
5.37\end{array}$ & $\begin{array}{l}2 \cdot 4 t \\
0.74 t\end{array}$ \\
\hline Ribonucl & $\begin{array}{ll}\text { lease }(m g) \\
\text { (/I diet) }\end{array}$ & $\begin{array}{l}37 \cdot 6 \\
12 \cdot 26\end{array}$ & $\begin{array}{l}34 \cdot 3 \\
8 \cdot 00 * *\end{array}$ & $\begin{array}{l}28 \cdot 0^{* * *} \\
6 \cdot 68 * *\end{array}$ & $\begin{array}{c}30 \cdot 8 * \\
9 \cdot 2 \mathrm{I} *\end{array}$ & $\begin{array}{l}2 \cdot 0 \dagger \\
1 \cdot 04 t\end{array}$ \\
\hline
\end{tabular}

$\mathrm{TN}$, total nitrogen; $20 \mathrm{PN}$, protein- $\mathrm{N}$ insoluble in $20 \mathrm{~g}$ trichloroacetic acid/1.

Mean values for diet significantly different from those for diet SKF: ${ }^{*} P<0.05$, ${ }^{* *} P<0.01$, **** $P<0.001$.

$\dagger \mathrm{SE}$ reduced by covariance adjustment for age.

$\ddagger$ Contained: SKF, skim-milk powder and fat; SK, skim-milk powder; ASKF, soya-bean flour, spray-dried whey powder, skim-milk powder and fat; BSKF, fish-protein concentrate, spray-dried whey powder, skim-milk powder and fat; for details, see Table I.

$\S$ One unit of activity is the amount of enyzme which liberates $\mathrm{I} \mu \mathrm{mol} \mathrm{acid} / \mathrm{min}$.

the period $\mathrm{I}-4 \mathrm{~h}$ after feeding, the ratios for diets ASKF and BSKF were greater than unity.

Over the period $0-3 \mathrm{~h}$ after feeding, there were significant differences between diets in the cumulative passage of $\beta$-carotene; the smallest amount was collected when diet SKF was given (Fig. I). The ratio of the amount of $\beta$-carotene/g lipid in the duodenal digesta: the amount of $\beta$-carotene/g lipid in the diet was considerably less than unity throughout the $12 \mathrm{~h}$ postprandial period (Fig. 2). The ratio was highest during the ist hour after feeding for diets ASKF and BSKF, whereas for diet SKF the ratio was low $(c .0 .30)$ for the first $4 \mathrm{~h}$ after feeding and then higher $(c .0 .50)$ for the remainder of the $\mathrm{I} 2 \mathrm{~h}$ period.

The amounts of pancreatic fluid and enzymes secreted are shown in Table 6 and Fig. 3. Although the volume of fluid was higher during the period $6-12 \mathrm{~h}$ than during $0-6 \mathrm{~h}$ after feeding, the mean enzyme activities were greatest during the first $3 \mathrm{~h}$ after feeding. As in the earlier experiment (Ternouth, Roy \& Siddons, 1974) the SE of the 


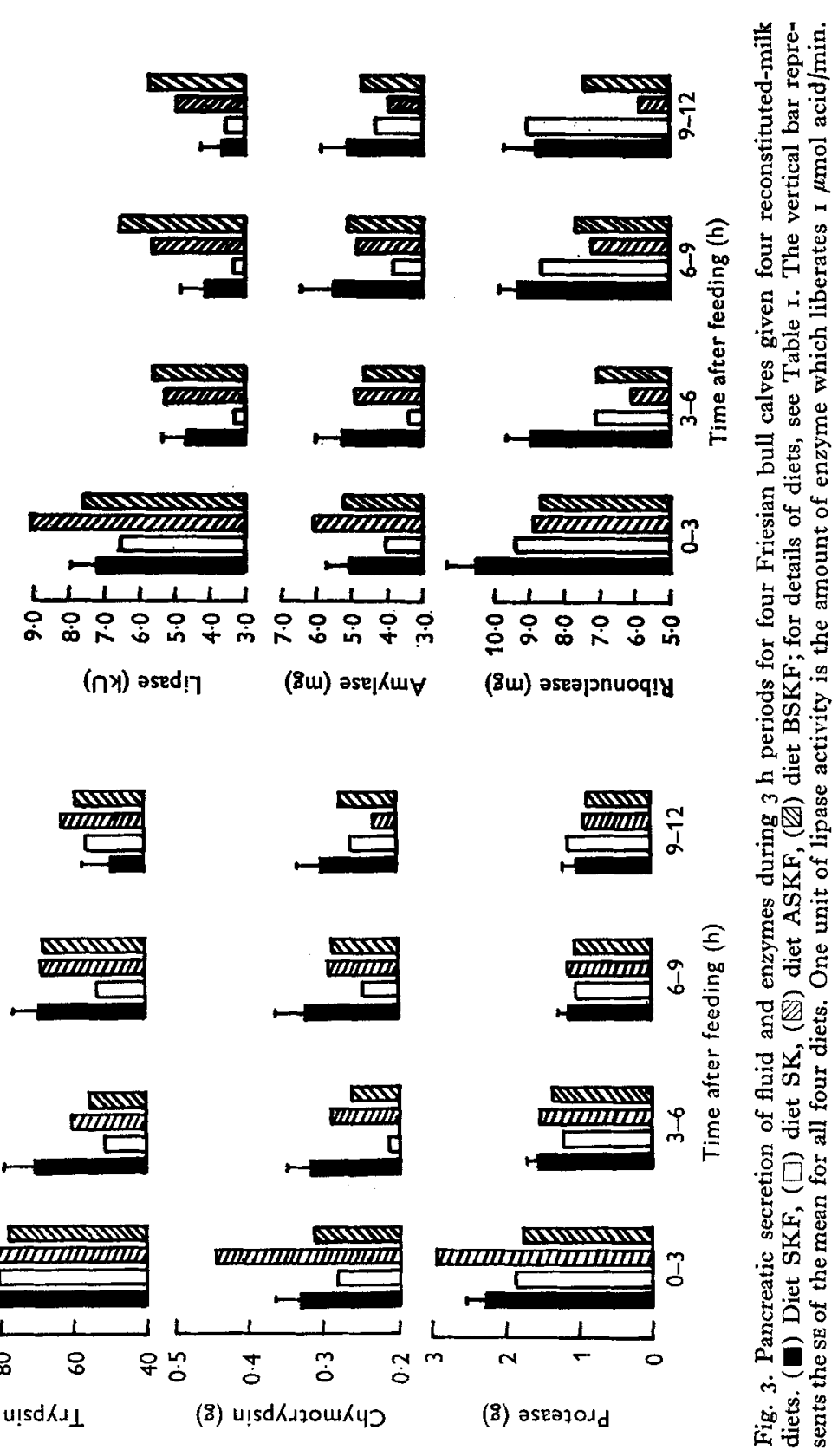


means were relatively large, even after adjustment for differences between treatments in the mean age of the calves. Thus, although the quantity of pancreatic fluid and enzyme activity was considerably lower with diet SK than with SKF, the differences were only significant for lipase activity or when the results were related to the quantity of diet ingested. The lipase activity found when diets ASKF and BSKF were given was significantly greater than for diet SKF, and ribonuclease activity was significantly less. The differences were apparent throughout the whole of the $\mathrm{I} 2 \mathrm{~h}$ postprandial period (Fig. 3). During the period $0-3 \mathrm{~h}$ after feeding, the secretion of trypsin, protease and lipase tended to be greater $(P<0.10)$ and chymotrypsin was greater $(P<0.05)$ for $\operatorname{diet}$ ASKF than for diet SKF. The total secretion of trypsin, chymotrypsin and protease activity per unit of protein $(2 \circ \mathrm{PN})$ passing through the duodenum tended to be less for diet ASKF and was significantly less for diet BSKF than for diet SKF.

\section{DISCUSSION}

Since the effects of feeding this particular soya-bean flour and fish-protein concentrate were unknown, only $50 \%$ of the skim-milk powder was replaced by these non-milk proteins. In vitro tests indicated that whereas diet ASKF did not clot on addition of rennet, diet BSKF formed a series of small, irregularly-shaped, granular clots, leaving a serous-coloured whey.

Two of the dietary markers used had limitations: (I) [ $\left.{ }^{3} \mathrm{H}\right]$ lysine-labelled goat's milk appeared to be quantitatively unsatisfactory for diets ASKF and BSKF, as the non-milk proteins were not completely soluble; (2) repeated ingestion of $\left[{ }^{3} \mathrm{H}\right]$ lysine resulted in increasing background radioactivity in the endogenous secretions; (3) the recovery of $\beta$-carotene from the lipid in the duodenal effluent was lower than that from the dietary lipid and was reduced also as the $\mathrm{pH}$ of the digesta fell below $6 \cdot 0$.

When the diets containing non-milk proteins were compared with diet SKF, no difference in the pattern of flow of $\mathrm{TN}$ or lipid through the duodenum was evident. That some partitioning of the ingested proteins occurred with diets ASKF and BSKF was indicated by values greater than unity for the ratio of the amount of $\left[{ }^{3} \mathrm{H}\right] \mathrm{lysine} / \mathrm{g}$ $\mathrm{TN}$ in the duodenal digesta: the amount of $\left[{ }^{3} \mathrm{H}\right] \mathrm{lysine} / \mathrm{g} \mathrm{TN}$ in the diet, $\mathrm{I}-4 \mathrm{~h}$ after feeding. Thus the high cumulative recovery after feeding diets ASKF and BSKF may be an over-estimate of the rate of passage of these non-milk proteins from the abomasum, because some $\left[{ }^{3} \mathrm{H}\right] \mathrm{lysine}$ may have been dissociated from the non-milk protein in the abomasum and may have passed out with the whey during the first $4 \mathrm{~h}$ after feeding. However, it is likely that the outflows of the ingested proteins of diets ASKF and BSKF were considerably more rapid than those of diet SKF, since $84 \%$ of ingested ${ }^{3} \mathrm{H}$ was recovered in the duodenal digesta during the $12 \mathrm{~h}$ after a calf was given whole milk which had been heated to $85^{\circ}$ for 30 min to prevent coagulation (Ternouth, 1971). More rapid outflow was also suggested by the finding that duodenal digesta: diet ratios for the amount of $\left[{ }^{3} \mathrm{H}\right] \mathrm{lysine} / \mathrm{g}$ TN for diets ASKF and BSKF were consistently higher than those for diets SKF and SK throughout the whole $\mathrm{I} 2 \mathrm{~h}$ collection period. Moreover, the multiple regression equations relating TN and lipid outflow to dietary intake showed that the outflows were related to 
dietary intake at the 'penultimate' meal when diets SKF and SK were given, but for diets ASKF and BSKF, the outflows were related to dietary intake at the 'experimental' meal. The different patterns of significant coefficients when coagulating and non-coagulating diets were fed have been found previously (Ternouth, Roy \& Siddons, 1974).

The duodenal digesta: diet ratios for the amount of $\beta$-carotene/g lipid was significantly higher for diets ASKF and BSKF than for diet SKF during the first $2 \mathrm{~h}$ after feeding. This difference is likely to be due to the failure of diets ASKF and $\mathrm{BSKF}$ to coagulate adequately. The pattern of flow of lipid and $\beta$-carotene through the duodenum during the remainder of the postprandial period did not suggest any marked difference between diets SKF, ASKF and BSKF.

The pattern of secretion of pancreatic enzymes was similar to that observed by Ternouth, Roy \& Siddons (1974), the highest secretion rate occurring during the period o- $\mathrm{I} h$ after feeding, with a continuous decrease thereafter until the end of the collection period (Ternouth, I97I). There was some increase in the rate of amylase and ribonuclease secretion during the period $5^{-12} \mathrm{~h}$ after feeding. As the zymogen granules and pancreatic secretions contain enzymes in the same proportions (Greene, Hirs \& Palade, I963), any change in the proportional quantities of the different enzymes secreted within a $\mathrm{I} 2 \mathrm{~h}$ period is likely to be due to changes in the rate of enzyme synthesis. Nakajima \& Magee (1970) have found that intravenous infusions of glucagon or glucose caused a preferential inhibition of secretion, in the order: amylase < lipase $<$ protease. In the present experiment the stimulus for the increased synthesis of amylase during $5^{-12} \mathrm{~h}$ after a meal is not clear. Decreasing concentrations of blood glucose (Martin, Ramsey, Matrone \& Wise, 1959) or increasing intestinal absorption of fat (Shannon \& Lascelles, I967) appear to be the most likely causes.

In the present experiment, the maximal rates of secretion of trypsin and protease coincided with the peak rate of TN and protein flow through the duodenum, both of which occurred during the first hour after feeding. However, the subsequent relationship between the quantity of TN flowing through the duodenum and the secretion of these enzymes was poor. Similarly, high outflows of lipids were also recorded during the period $5^{-1} 2 \mathrm{~h}$ after feeding without a corresponding increase in the rate of secretion of lipase. These results especially when combined with those of Ternouth, Roy, Stobo, Ganderton, Gillies \& Shotton (1974), suggest that adsorption of the pancreatic enzymes is of importance in maintaining the hydrolytic activity within the small intestine.

The effects of exclusion of additional fat from a skim-milk diet are in agreement with the results reported earlier (Ternouth, Roy \& Siddons, 1974). As judged by the ( $\mathrm{Cl}^{-}$ minus $\mathrm{Na}^{+}$) concentration in the apparent secretions, diet SK caused more acid to be secreted in the $\mathrm{r} 2 \mathrm{~h}$ period than did diet SKF, but the volume of pancreatic fluid was less. Compared with the other diets, less ingested protein of diet SK flowed from the abomasum than protein $(20 \mathrm{PN})$ although the quantity of nitrogenous material (I00PN) did not differ significantly between diets. This greater amount of abomasal proteolytic activity with diet $\mathrm{SK}$, together with the tendency for less of the $\left[{ }^{3} \mathrm{H}\right] l y$ sine to be recovered during the $\mathrm{I} 2 \mathrm{~h}$ period, may have been because the physical absence 
of fat globules increased the accessibility of the peptide bonds to enzyme hydrolysis or increased the number of bonds needing to be hydrolysed to allow release of the peptides from the more solid coagulum formed on this diet, or both. Casein represents 77 and $80 \%$ of the milk proteins in goat's milk and skim-milk powder respectively (Ling, Kon \& Porter, 196r). Assuming that all the non-casein protein had left the abomasum with the whey fluids, then when diet SK was given, less casein tended to leave the abomasum in a $12 \mathrm{~h}$ period $(32 \%$ and $22 \%$ of the casein for diets SKF and $\mathrm{SK}$ respectively $(P<0 \cdot \mathrm{IO}))$. There is no obvious reason for the lower rate of secretion of the pancreatic enzymes (including lipase) with diet SK, a finding in agreement with the result of Ternouth, Roy \& Siddons (1974). As increased outflows of undigested protein were found when diets SKF, ASKF and BSKF were given, in the present experiment, it can be concluded that the reduction in secretion of pancreatic fluid and enzymes is the result of the lack of dietary fat.

The quantity of lipid passing through the duodenum of the calves caudal to the bile duct, in a $\mathrm{I} 2 \mathrm{~h}$ period after being given diet SK, was $4 \mathrm{~g}$ more than the quantity of lipid ingested, equivalent to a daily outflow of about $160 \mathrm{mg} / \mathrm{kg}$ live weight. This lipid is likely to be of biliary origin. Adams \& Heath (1963) found that adult sheep secreted Io-15 $\mathrm{g}$ bile phospholipid/d. The value of $160 \mathrm{mg} / \mathrm{kg}$ live weight may be compared with the estimates of $20-50 \mathrm{mg}$ endogenous faecal lipid/kg live weight found by Cunningham \& Loosli (r954) and Roy, Stobo \& Gaston (r970) in preruminant calves, which suggests that about $100 \mathrm{mg}$ biliary lipids per $\mathrm{kg}$ live weight are reabsorbed.

When diet ASKF (soya-bean flour) was given there was no reduction, compared with diet SKF, in the outflow of pancreatic fluid, trypsin, chymotrypsin, protease or lipase, but when related to dietary intake some reduction occurred. The soya-bean flour used in our experiment was 'chemically treated' to inactivate the soya-bean trypsin inhibitor and this inactivation could explain why our results differed from those of Gorrill et al. (1967). When diet BSKF (fish-protein concentrate) was fed, the secretion of enzymes, with the exception of lipase, both in absolute amounts and when related to dietary intake, tended to be lower than when diet SKF was fed.

Both milk-substitute diets containing non-milk proteins appeared to be satisfactory for the $6 \mathrm{~d}$ feeding period and the intakes of both were relatively high, the intake of diet ASKF tending to be higher than that of diet SKF. In the present study, when the skim-milk powder was partially replaced in the diets, neither the massive reductions in the secretions of pancreatic enzymes (Gorrill et al. 1967) nor the changes in the pattern of duodenal outflow (Colvin et al. 1969; Smith, Hill \& Sissons, I970) associated with the feeding of soya-bean protein were found. Nevertheless, in the present experiment the reduction in pancreatic enzyme secretion and the more rapid passage of the undigested protein from the abomasum may be sufficient to produce the reduction in growth rate found, especially during the first 3 weeks of life, in calves given diets similar in composition to ASKF and BSKF (J. H. B. Roy, I. J. F. Stobo, S. M. Shotton \& P. Ganderton, personal communication). 
The authors acknowledge the assistance of Dr V.A. Welch with the preparation of the $\left[{ }^{3} \mathrm{H}\right]$ lysine-labelled goat's milk and the members of the Biochemistry Department for their assistance with the measurement of radioactivity. Mr E. Florence and Mrs M. Le Fort are thanked for assisting with the nitrogen and lipid estimations. J.H.T. gratefully acknowledges the financial assistance of the Australian Dairy Produce Board.

\section{REFERENCES}

Adams, E. P. \& Heath, T. J. (1963). Biochim. biophys. Acta 70, 688.

Colvin, B. M., Lowe, R. A. \& Ramsey, H. A. (1969). Y. Dairy Sci. 52, 687.

Colvin, B. M. \& Ramsey, H. A. (1969). F. Dairy Sci. 52, 270.

Cunningham, H. M. \& Loosli, J. K. (I954). F. Dairy Sci. 37, 453.

Folch, J., Lees, M. \& Sloane Stanley, G. H. (1957). F. biol. Chem. 226, 497.

Gorrill, A. D. L., Thomas, J. W., Stewart, W. E. \& Morrill, J. L. (1967). F. Nutr. 92, 86.

Greene, L. J., Hirs, C. H. W. \& Palade, G. E. (1963). F. biol. Chem. 238, 2054.

Hummel, B. C. W. (1959). Can. F. Biochem. Physiol. 37, I 393.

Kon, S. K. \& Thompson, S. Y. (1957). Milchwissenschaft 12, 166.

Ling, E. R., Kon, S. K. \& Porter, J. W. G. (1961). In Milk: The Mammary Gland and Its Secretion Vol. 2, p. 195 [S. K. Kon and A. T. Cowie, editors]. London: Academic Press.

Marchis-Mouren, G., Sarda, L. \& Desnuelle, P. (1959). Archs Biochem. Biophys. 83, 309.

Martin, W. G., Ramsey, H. A., Matrone, G. \& Wise, G. H. (1959). F. Dairy Sci. 42, 1377.

Mattson, F. H. \& Volpenhein, R. A. (1969). F. Lipid Res. 10, 27 I.

Nakajima, S. \& Magee, D. F. (1970). Can. F. Physiol. Pharmac. 48, 299.

Nelson, G. J. \& Freeman, N. K. (I959). F. biol. Chem. 234, 1375 .

Neurath, H. (1962). Ciba Fdn Symp. p. 67.

Paruelle, J. L., Toullec, R., Frantzen, J. F. \& Mathieu, C. M. (1972). Annls Zootech. 21, 319.

Roy, J. H. B., Stobo, I. J. F. \& Gaston, H. J. (1970). Br. F. Nutr. 24, 459.

Shannon, A. D. \& Lascelles, A. K. (1967). Aust. F. biol. Sci. 20,669.

Smith, R. H., Hill, W. B. \& Sissons, J. W. (r970). Proc. Nutr. Soc. 29, 6A.

Smith, R. H. \& Wynn, C. F. (1971). Proc. Nutr. Soc. $3^{\circ}, 75^{\mathrm{A}}$.

Ternouth, J. H. (1971). Studies of the role of the abomasum and pancreas in digestion in the young calf. PhD Thesis, University of Reading.

Ternouth, J. H. \& Buttle, H. L. (1973). Br. F. Nutr. 29, 387.

Ternouth, J. H., Roy, J. H. B. \& Siddons, R. C. (1974). Br. F. Nutr. 3r, r3.

Ternouth, J. H., Roy, J. H. B., Stobo, I. J. F., Ganderton, P., Gillies, C. M. \& Shotton, S. M. (1974). Br. F. Nutr. 32, 37.

Worthington Biochemicals Corporation (1972a). Worthington Enzyme Manual p. 129. Freehold, New Jersey: Worthington Biochemicals Corp.

Worthington Biochemicals Corporation (1972b). Worthington Enzyme Manual p. 63. Freehold, New Jersey: Worthington Biochemicals Corp. 